\title{
epiphany
}

Journal of the Faculty of Arts and Social Sciences

International University of Sarajevo

ISSN 1840-3719 / No. 2

Spring 2009

\section{Exporting EU Liberalism Eastwards}

\author{
Lynn Tesser \\ International University of Sarajevo
}

A central ideological justification for Central and East European (CEE) countries joining key international institutions lies in what Aleksander Smolar and Magdalena Potocka named the last great myth of 1989: the return to Europe (Smolar and Potocka 12). Yet, the very idea of Europe is fraught with contradiction and complexity for having represented diverse things over the course of several centuries - from Christendom to the balance of power system. Nevertheless, Western Europe acquired a monopoly on the term during the Cold War, limiting the 'Europe' of 'return to Europe' fame and fortune to its positive characteristics: wealth, democracy, market economies, human rights, and civilization. What the 'return to Europe' as an ideology ultimately means is the re-unification of the two formerly separated parts of geographical Europe, with the drab, less well off, and more traditional 'East' mirroring the sparkling, rich, and modern 'West.'

At the immediate end of the Cold War, the return trip meant first and foremost re-establishing civil society to ensure individual and societal freedoms. The emphasis on civil society was a legacy of communism, a time when the formal realm of politics was not only out of reach for most, but taken to be inherently corrupt. The idea of forging a 'third way' between capitalism and socialism also gained ground to avoid the empty consumerism of the former and the coerciveness of the latter. The second path towards Europe, one that would gain in prominence as indigenous civil society and third way ideologies faded, was through joining all key pan-European and international organizations: the OSCE, OECD, NATO, EU, and 
the Council of Europe (COE). ${ }^{1}$ Among these, the EU stands out for having the most extensive demands for reform, namely the requirement that incoming states adopt the acquis communitaire.

Along with the idea of returning to Europe, 'democracy and markets' rose in importance as ideological staples of CEE's transformation. The emphasis on markets and democracy had both domestic and international catalysts. Domestically, both were taken to be the sources of West European peace and prosperity, an assumption that gave these ideas the shiny patina lost decades ago in the West. Internationally, democracy and markets were celebrated globally after the end of the Cold War. Their promotion was not limited to Europe, but extended also to U.S. foreign policy. Yet, the difference between the 'markets' stressed by the neoliberal Washington Consensus and those stressed by Brussels was indeed stark. While the former wanted states excused from the process of creating markets, the latter preferred an institutional makeover for states to create a new framework within which to embed emerging markets (Bruszt 128).

To be sure, the rise of democracy (and democratization) in CEE has attracted far greater scholarly attention than liberalism. In 1989, the central question was how to develop democracy and capitalism simultaneously with international institutions understood as a way to further consolidate democracy and markets already created by domestic forces. Later, one group of scholars began to emphasize the influence of institutions and consequently questioned whether the nature of the integration process (particularly via the adoption of the EU's aquis) might lead to the unfortunate export of the EU's infamous 'democratic deficit' to CEE (Holmes, Grabbe, Grzymala-Busse and Innes). Other scholars predicted that the EU accession process would help create a group of 'dependant democracies' in place of mature EU member states (Jacoby).

1 Certainly, emphasis on creating civil society has continued through the involvement of international institutions. 
The few existing studies on liberalism, on the other hand, focus on the domestic determinants of liberalism with some attention given to international financial institutions' influence in laying the ground for market economies (Szacki, Suda and Musil, Frankel Paul et al). This article will illustrate that there is much more to liberalism in the postcommunist context than has been acknowledged. A sizeable effort has indeed emerged to transplant a relatively coherent liberal ideology to the region, one exported not merely through the conditionality of international financial institutions, but also through the conditionality and socialization of organizations like COE, OECD, NATO, OSCE, and EU.

Socialization and membership conditionality have been the two methods of bringing EU liberalism to Central and East European countries (Kelly 2004 19). Used to the greatest extent by the OSCE which admitted most CEEs relatively quickly after 1989 and several countries during the Cold War, normative pressure or socialization involves efforts to get CEE elites to change policy in line with postCold War norms without making membership conditional on doing so. Beyond creating the post of the OSCE High Commissioner on National Minorities (OSCE HCNM) in December 1992 as a conflict prevention measure, one that helped raise the organization's profile once the EU began to consult the OSCE HCNM on a regular basis, the OSCE used other means to influence minority policy that fit within the rubric of normative pressure: (1) the establishment of field offices (or missions) within countries thought to have the potential for conflict to monitor treatment of minorities and to interact regularly with officials, (2) short-term visits by experts and/or elites from other OSCE member states to determine the extent to which these countries adopted policies in line with OSCE guidelines (Kelley 2004 17) (3) declarations and official statements evaluating current policies that might also indicate recommendations for future changes as well as the formal statement of norms in official documents such as the Copenhagen Document or the Framework Convention, and (4) dispatching teams of legal experts to provide advice during the 
policy-making process (Kelley 2002 14). Particularly unique to the OSCE's methods has been the establishment of missions that bring a small number of people in to work on a daily basis with local officials on a variety of issues -- not merely concerning human and minority rights, but also on topics such as strengthening independent judiciaries, the rule of law, and independent media.

Conditionality, on the other hand, has been used more by the COE, especially by the EU, and occasionally by NATO -- though the COE also used normative pressure to coax CEEs to adopt policies in line with post-Cold War norms. Conditionality creates greater incentives to change given linkages to membership in Europe's most prominent international institutions. EU conditionality has involved: (1) promises of aid and trade preferences, (2) monitoring and benchmarking (i.e. the submission of yearly progress reports that rank applicants' success in meeting membership requirements, other reports and decisions made at meetings requiring specific action by candidates, evaluations prior to formal accession negotiations to identify discrepancies between EU and national law), (3) accession negotiations that involved deliberations over 31 chapters as well as ongoing benchmarking and monitoring (Kelley 2002 14) and (4) declarations from the Presidency and resolutions from the European Parliament along with other official declarations and demarches urging reform (Kelley 2004 19). My use of the term 'conditionality' generally refers to either NATO and especially to EU membership conditionality.

\section{EU Liberalism as a 'Stealth Ideology'}

EU liberalism has three components: (1) the 'standard' liberal emphasis on individual rights, the rule of law, constitutional democracy, freedom, and market economics, (2) a rather unconventional support for minority rights (by contemporary norms), and specifically concerning the EU (3) a seemingly schizophrenic emphasis on economic integration that involves, first bringing down borders for the free movement of people, goods, capital, and services between 
member states, and second, market regulation to diminish the social downsides of capitalism. While many would question whether minority protections are indeed 'liberal,' they are nevertheless included for two reasons: (1) post-Cold War minority rights are heavily indebted to individualistic Cold War human rights doctrine, and (2) some liberals supported the idea of minority rights prior to the Second World War. The work of Will Kymlicka has done much to change how minority rights are conceptualized by claiming that formally unilingual and seemingly liberal countries such as the U.S. are inherently assimilationist.

Clearly, EU liberalism is much more than mere 'markets.' This may be why it is something of a 'stealth ideology' - a deeply-transforming politico-economic program that has not yet been fully represented in political discourse or considered by scholars. It is strikingly divorced from the locally grown notions of civil society and the 'third way' from 1989, which raises the question of whether it can be successfully incorporated. Concerning the two contradictory elements in EU liberalism's third distinguishing feature, Liesbet Hooghe and Gary Marks have referred to each as 'projects' forming the basis of official EU discussion concerning the organization's future trajectory since the 1980s. First is the 'neoliberal project' spurring competition between governments to create the most attractive conditions for firms and investment - thus, in a sense, getting states 'out of markets' way (or at least out of firms' way). Second is the 'project for regulated capitalism' that increases EU regulation over the Single Market for the purpose of mitigating capitalism's negative social outcomes. The pursuit of these projects, in effect, exchanges national governments' control over their individual domestic markets for EU regulation over the enlarged market. Some would argue that doing so ultimately increases domestic governments' control in the first place through allowing regular and legitimate involvement in their neighbors' domestic affairs (Moravscik 485-6). While both sit uneasily together, these two projects indeed reflect the contradiction in liberalisms mixing a high regard for 'negative liberties' -- rights that keep 
governments and others from coercively interfering in individuals' lives - with varying degrees of support for 'positive liberties' - state entitlements aimed at increasing equality of opportunity. Mark Pollack rightly notes that the neoliberal project has had greater emphasis as primary EU treaties have made the creation of the Single Market a high priority even while also mandating its regulation (Pollack 268).

EU liberalism is an ideology that has essentially developed outside of CEE and has at least two primary sources: (1) the effort to create a harmonized European market among rich, highly developed West European economies, and (2) West European concerns about post-Cold War security that sparked the development of the post-Cold War minority rights regime exclusively for CEE states. The requirement that CEE economies adopt Single Market policies and the post-Cold War minority rights regime then leads to the question of what happens when, in Jerzy Szacki's words, such ideas "are transported to entirely different conditions from those in which they originated" (Szacki 12). Ironically, EU liberalism is the polar opposite of the ideology orienting the drive to create ethnically homogenous states during and after the Second World War, an ideology strongly favoring state support for particular nationalities. While political liberalism may indeed be less appealing for state-possessing majority nationalities as it fractures majority rule, more problematic for the region are the implications of EU liberalism's export: (1) a sizeable shift away from official state support for particular nationalities stemming both from the minority rights regime and anti-discrimination principles embedded in the four Single Market freedoms (free movement of people, goods, capital, and services), and (2) the frequent disjuncture between rhetoric and reality in regard to anti-discrimination principles, one that can diminish the credibility of liberal values. For example, Western Europe is not required to adhere to the postCold War minority protection regime, and while CEE has been brought into the EU's market regulation scheme, older member states have been keener to protect 
sensitive industries there than to diminish the social and economic dislocations of capitalism.

Considering Western Europe's post-Second World War 'velvet revolution,' Mark Lilla reminds us that this half of the continent only grudgingly accepted liberalism over the course of decades, an acceptance that was anything but preordained, and only likely condoned because of economic growth and adequate social-welfare policy' (Lilla 133). As the West European precedent suggests, economic growth and social welfare were key to the acceptance of liberal values. A great deal of hope in CEE rests on the EU to deliver an increased standard of living and overall economic development in CEE. Yet, there has neither been an emphasis on social protection in exporting EU liberalism nor has the region ever come close to West European levels of development historically - with the exception of the Czech Lands and Hungary. David Good's comparative analysis of CEE countries' historical economic growth, after all, indicates that CEE's position relative to other European states from 1870 to 1989 remained relatively unchanged (Good 50). When combined with EU liberalism's illiberal export, such conditions do not bode well for liberalism's future in much of the region.

\section{The Illiberal Rise of EU Liberalism}

Without a doubt, many CEE citizens desired political and economic change along liberal lines after 1989 including: (1) the creation of pluralist party systems; (2) the recognition of human rights in order to ensure basic individual freedoms; and (3) the creation of market economies. Domestic support for some of the 'standard liberal' elements in EU liberalism no doubt existed. Less popular, however, was the idea of minority rights as well as of substantially reducing state control over capital markets and especially land markets in favor of foreign investment. Rogers Brubaker, Katherine Verdery, and others have shown why national majorities did not embrace minority rights after the end of the Cold War, all 
of which used nationalism as a way to establish their respective states' de facto independence. Retaining state control over land and capital flows runs along the same lines to protect 'national' interests.

The emergence of EU liberalism began with various aid programs and institutions: the creation of the European Bank for Reconstruction and Development (EBRD), IMF aid, and a new program called Poland and Hungary: Assistance for Restructuring Their Economy (PHARE). EU member states created the EBRD in 1990 to provide aid to CEE in the form of technical assistance, policy advice, security offerings, and equity investment. The conditions of its receipt emphasized political over economic reform: respect for basic human rights, acceptance of a multiparty system, respect for the rule of law, free but secret elections, and finally policies laying the groundwork for market economies.

IMF conditionality was more expressly economic with the receipt of financial assistance conditional on the country's performance and adherence to a previouslyagreed upon timetable of reforms comprising a market-creating program. Though varying for each CEE country, the primary elements of mandated reforms included: privatization, substantial trade liberalization, restrictive credit and monetary policies, rapid and almost complete price liberalization, the reform of banking and financial systems, tight fiscal discipline (including near total elimination of price subsidies), and changes in incomes policies (Senior Nello 84-5). Given that the early postcommunist governments had a stronger preference for neoliberal economic reform (as the opposite of and seemingly necessary antidote to communist economics), the IMF program met with approval. Though the effects of markets would soon lead to economic and social dislocation, at least at the outset the EBRDand IMF-driven reforms had social support.

Finally, PHARE became the primary aid program for CEE. It was originally aimed at providing non-returnable financial assistance to Poland and Hungary for the express purpose of helping these countries go from planned to market 
economies and was quickly expanded to encompass all CEE states. ${ }^{2}$ Application to PHARE had conditions similar to the EBRD: the establishment of a multiparty political system, respect for human rights, the organization of free elections, and the creation of market economies (Maresceau 12).

\section{Promoting Minority Rights}

Divergence between CEE desires and international institutions' conditionality began, however, with the emphasis on minority rights. While liberals and others in CEE countries supported the idea of providing minorities with basic human rights, the emphasis on minority protection came more from West European states noting, first, that ethnic conflict over minorities was a key security threat after the erosion of the U.S.S.R.'s control over CEE, and second, that such conflict could potentially destabilize Western Europe through the westward movement of refugees and immigrants. Heather Grabbe has noted, in fact, that unrestricted immigration from eastern countries essentially replaced the threat of a Soviet invasion as Western Europe's key security concern, at least with respect to the East (Grabbe 2000 520). It was thus of paramount importance, from the perspective of these countries, to provide incentives to encourage CEE minorities to stay put - though much less so for state-possessing nationalities.

The primary international organizations working on the minority rights issue were the OSCE and the COE. The OSCE's 1990 Paris summit demonstrated clear commitment to liberal values in committing member states to the following actions: to hold free and fair elections, to respect the rule of law, to uphold the rights of national minorities, to respect human rights and fundamental freedoms, and to promote free markets (Weitz 1992). Likewise, the COE required prospective member states to "accept the principles of the rule of law and of the enjoyment of all

\footnotetext{
2 After a July 1989 meeting of the G-7, the European Commission was given the task of coordinating the PHARE program.
} 
persons within its jurisdiction of human rights and fundamental freedoms." 3 While the OSCE played a greater role in developing the contemporary minority rights regime, the COE put more effort into developing uniform criteria and has had more leverage on CEE states concerning its implementation. Not only did several CEE countries join the OSCE long before 1989 (Bulgaria, Romania, and Poland joined in 1973), but the OSCE's power to realize the regime in CEE was mitigated by its status as a traveling conference. It only began to metamorphasize into an international organization after rising to the challenges of the immediate post-Cold War era.

By the mid-1990s, the OSCE and the COE had developed a distinct minority rights regime, one that centered around three standard-setting documents: the OSCE's 1990 Copenhagen Document, the OSCE's 1991 Geneva Report, and the Council of Europe's 1995 Framework Convention for the Protection of National Minorities. Defined as "individuals belonging to national minorities," the benefactors of new European norms would have rights to: define their identity, have full access to human rights accorded to all, be equal before the law and thus free from state-sponsored discrimination, and to maintain and develop their own culture.

The regime that emerged was essentially the product of two radically opposed views on minority protections. On the one hand, statist-oriented countries such as Greece, France, Bulgaria, Romania, and Slovakia demanded that these rights be framed in individualistic human rights language. On the other hand, countries with significant numbers of 'kin' abroad such as Hungary and Germany promoted more extensive protections to discourage those identifying themselves as Hungarians and Germans from moving to their respective 'mother' states. For Hungary in particular, it was a matter of keeping Hungarians living in areas that had previously belonged to Hungary. The former view clearly prevailed as primary

$3 \quad$ Article 3 of the Council's Statutes quoted in Weitz (1990 50). Beyond this, a key membership requirement was that each state's delegation to the Council must be composed of representatives from all prominent political parties. 
post-Cold War treaties referenced 'individuals belonging to national minorities' rather than to 'national minorities.' Yet, it is possible to take a more collectivist view given that several of the rights delineated are actions that usually occur in the presence of others -- for example, the right of cultural preservation through festivals and publicly-celebrated holidays, the use of minority languages in the private and public spheres, and the ability to create organizations (Tesser 486).

Though the COE and OSCE put a good deal of effort into developing post-Cold War standards on minority protections, the existence of genuine pressure to adopt them might seem questionable given the minimal enforcement mechanisms at the Council's and especially the OSCE's disposal. Yet, pressure did exist, stemming from the fact that most CEE states very much desired EU entry and membership in the COE became a de facto prerequisite for joining the EU by 1993 (Switalski 27). This setup thus provided the COE in particular with the leverage to persuade CEE elites to adopt such policies.

However, it is also true that the EU's rhetorical support for minority rights was belied by two things: (1) West European states were not under similar pressures; making it quite ambiguous whether human rights really mattered to the EU (Sadurski 5), and that (2) Germany has been a key sponsor of EU expansion eastwards, a leading European power that itself defines de facto membership on ethnic blood ties. Germany's influence, in fact, has led the EU-15 to favor parties with the strongest pro-Western attitudes while not making a great deal of their nationalist politics.

\section{Promoting the Single Market}

As for minority rights, CEE societies were not enamored of all Single Market freedoms equally, especially ending formal state control over land and capital markets allowing foreign ownership. The Central and Eastern Eurobarometer, in fact, indicates a general lack of support for foreign ownership in the region ranging 
from $64 \%$ against in Lithuania (in 1993) to a low of $24 \%$ against in Hungary (in 1993), with Hungary unusually open to foreign firms in the 1990s -- though less so to foreign land ownership.

Pressures to take on the characteristics of the EU's Single Market arose around the same time as the emergence of the new European minority rights regime. In fact, early EU involvement with CEE countries had far more to do with the promotion of the Single Market than with human or minority rights. The EU made numerous bilateral agreements - Europe Agreements - with CEE states to establish formal trade relations, East-West cooperation, and to promote the practices of the Single market - particularly the free movement of goods, capital, services, and labor across borders over a ten-year period, ultimately helping to restructure CEE economies to bring them more in line with the EU's Single Market (de Weydenthal 1992 25). Yet, the Commission made it clear in a 1990 announcement that the purpose of the Agreements was NOT to lay the grounds for accession, but instead to develop incentives for reform in CEE countries and to protect EU interests.

Requirements for being considered a candidate for a Europe Agreement signaled clear intention to promote reforms in line with EU liberalism: "the introduction of the rule of law, the respect for human rights, the establishment of a multi-party system with corresponding free and fair elections and finally, the introduction of a market economy" (European Information Service). According to the Agreements, the desired integration of the European market mandated that CEE countries alter existing laws to conform with EU law; albeit without requiring these countries to give evidence of their immediate success (Cernat 9).

For the most part, the Europe Agreements promoted anti-discrimination policies by laying down reciprocal rights for the EU and CEE countries to establish firms and other enterprises on each other's territory (de Weydenthal 1992 25). However, there were key exceptions. While existing member states offered 
favorable trade terms - with the EU making concessions to CEE before the latter reciprocated, sensitive EU-15 industries such as agricultural products, textiles, coal, and steel were protected from CEE competition. Customs duties on CEE products from these sectors would be eliminated at a slower rate than on other imports. Beyond that, CEE countries had to open their respective markets to heavily subsidized West European agricultural products non-tariff barriers - regulations involving labeling information and the specific ways plants and animals are handled that - have often kept CEE goods from circulating freely in the Single Market.

Indeed, the EU appears the most 'socialist' when it aims to protect the interests of older member states. A perfect example concerns EU control over steel production in Poland. Preston Keat's insightful article on an agreement between the Polish government, Polish steel manufacturers $185 \%$ of which had been owned or controlled by the government), and the EU presents strong evidence for an 'EU socialism' in older member states' interests that runs against the principles of EU liberalism. While cautious market forecasts predicted an increase in the domestic demand for steel from 2000 to 2010, the settlement limits domestic production to 13.5 million tons by 2002, thus reducing profits that might otherwise have been made. The agreement ultimately leads to a decrease in production that is not driven by market forces, but because of a deal made to keep all steel plants (even inefficient ones) functioning. Along with financial help from the EU, the Polish government offsetting this loss of potential profit by investing $\$ 2.5$ billion towards modernization in nearly all the country's 24 steel plants between late-1998 and 2005. While approximately 40,000 steel workers would be laid off, they would receive more than ample benefits compliments mostly of the EU. Keat sums up the situation accordingly: “... what the EU deal really does is legitimate some form of systematic government intervention in the industry that might otherwise not have occurred. It also highlights the fact that organized interests in Western Europe were able to get what they wanted - reduced competition from Poland" (Keat 219). In 
summary, the regulation of capitalism in a broader Europe, often to the tune of older EU members' preferences, belies the non-discrimination rhetoric intended for candidate countries.

EU hesitation in offering membership and later delaying candidates entry certainly did not help matters. After being asked when Poland would become an EU member, for example, Poland's former Foreign Minister Władysław Bartoszewski signaled just this much by indicating that the science fiction writer Stanisław Lem would be more likely to know (Bartoszewski 71). The EU has indeed used various methods to stall the expansion process that have, at times, delivered a great deal of frustration to applicant states. The EU signed the Europe Agreements beginning in 1991, after all, not merely to lay the basis for formal association and stimulate liberalization, but also to essentially put off the question of whether these countries would be allowed to join. When requesting formally that their progress towards possible membership be assessed in September 1992, Hungary, Poland, and Czechoslovakia received a rather ambiguous response with nothing concrete on the possibility of their entry (de Weydenthal 1993 29). Though the EU sent progressively stronger positive signals beginning in 1993, the primary stalling tactic in the second half of the 1990's was to continually push back the projected date of entry, or even more frustrating for the candidates, to change the requirements of admission.

Combining Minority Rights and Single Market Freedoms in the Pre-Accession Process

Only during the June 1993 European Council summit in Copenhagen did more concrete promises for accession emerge. Though no timetables were established, nor were specific countries invited to begin accession negotiations, the Council provided a clear statement of intent: "Accession will take place as soon as an associated country is able to assume the obligations of membership" (Bulletin). The essential conditions for joining established at Copenhagen signal that EU liberalism, 
building off the conditionality of the Europe Agreements and the emerging minority rights regime, had indeed taken shape in the simultaneous emphasis on minorities and markets: (1) the existence of stable democratic institutions including rights, respect for, and protection of minorities as well as the rule of law; (2) the presence of a market economy capable of withstanding competitive pressures; and (3) the ability to take on all of the requirements that come with membership, including monetary, economic, and political integration. Shortly afterwards, the EU launched the 1994-1995 Pact for Stability for the purpose of encouraging CEE states to reach formal agreements with their neighbors concerning the treatment of minorities as well as borders (Smith 122).

At the same time, the EU began to lay the grounds for accession by developing a specific preparatory framework for entry. The 'pre-accession process' increased the amount of pressure on CEE hopefuls to harmonize with EU law and policy. During the first half of the 1990 s, prospective members were only to make some effort in approximating EU law. This began to change with the European Commission's 1995 publication of the White Paper on the "Preparation of the Associated Countries of Central and Eastern Europe for Integration into the Internal Market of the Union." The White Paper's purpose was to present guidelines to help associate countries prepare for potential membership - specifically to help CEE countries undertake reforms the Commission deemed essential for the functioning of the Single Market. Prohibiting discrimination on the grounds of nationality, the White Paper emphasized implementing the four main Single Market freedoms concerning goods, services, people, and capital (White Paper).

Pressure to adopt Single Market policies increased with the development of Agenda 2000 in 1997, a Commission document meant to satisfy Council demands for creating a monitoring process for candidate states. Agenda 2000 was the Commission's effort to present "in a single framework the broad perspectives for the development of the Union and its policies beyond the turn of the century" 
(Agenda 11). It reiterated some of the Copenhagen goals in delimiting three areas of concern: (1) democracy and the rule of law, (2) human rights, and finally (3) respect for minorities. Interestingly enough, Agenda 2000 stressed human and minority rights more than the development of the Single Market. This was likely due to concern over CEE candidates' 'hot spots' - Russians in Estonia and Latvia and particularly Hungarians in Slovakia - as well as continued concern over the region's Roma. Cynics claimed that doing so would give the EU means to delay the expansion process.

At the same time, pre-accession dictated that candidate countries would be subject to reports on their progress. In July 1997, the Commission published its opinions (avis), documents outlining the extent to which the entrants had met the Copenhagen criteria and the steps needed to completely fulfill them. To simplify matters, the EU created the Accession Partnerships to bring the different forms of pre-accession assistance into one package, prioritizing those areas acutely in need of work. Thereafter, EU demands became more explicit and aid was directed exclusively toward meeting the requirements of accession (Grabbe 1999 15). At the same time, the EU made an effort to more outwardly express its drive to promote liberal values. Following revisions undertaken in the 1997 Amsterdam Treaty, the Treaty on European Union states: "the Union is founded on the principles of liberty, democracy, respect for human rights and fundamental freedoms, and the rule of law, principles which are common to Member States" (Laffan 341).

Particularly with the Accession Partnerships, PHARE became explicitly concerned with helping candidates to adopt the aquis, rather than to meet more general political and economic objectives established by the entrants themselves (Grabbe 1999 16). Later, additional aid programs were created to help applicants meet the demands of pre-accession: the Structural Adjustment Program for Agricultural and Rural Development (SAPARD), the Pre-Accession Structural Instrument (ISPA) (concerning structural policies), and later Community Assistance 
for Reconstruction, Development, and Stabilization (CARDS) for Albania and the states of the former Yugoslavia (Maresceau 35).

While the Accession Partnerships do not have a base in any treaty or bilateral agreement (as they are entirely EU-initiated), they have made the Copenhagen conditions "quasi-legal" by creating a series of sanctions and a control procedure and have ultimately become the main documents orienting CEE-EU relations (Grabe 1999 17).4 Heather Grabbe rightly notes that the Accession Partnerships hold limited understanding of how market economies should appear, uniformly minimizing the role of varied social actors in industry and the economy in general along Anglo-American neoliberal lines (Grabbe 1999 21).

\section{Conclusion}

The 1990s witnessed the rise of EU liberalism in CEE, a 'stealth ideology' promoted primarily through the conditionality of key international institutions that remained quite unknown to societies uncertain of all the policy changes needed to 'join Europe.' Its emphasis on minorities and border-effacing markets indeed runs quite contrary to ideas of civil society and the 'third way' emerging at the immediate end of communism - not to mention the drive to create ethnically pure states of the $20^{\text {th }}$ century. Nevertheless, CEE elites' and societies' desire to 'return to Europe' - a return essentially defined by West European elites and key international organizations - would mean adopting a program of specific reforms laid out by the West and designed, to a large extent, to satisfy West European interests in furthering the Single Market and preventing population flows from the East.

At least up until the time of entry, the asymmetrical nature of the EU-CEE relationship contributed to EU liberalism's illiberal transfer with EU member states acting as 'players in the game' who simultaneously had the power to determine who

\footnotetext{
$4 \quad$ Heather Grabbe rightly notes that the Accession Partnerships hold limited understanding of how market economies should appear, uniformly minimizing the role of varied social actors in industry and the economy in general along Anglo-American neoliberal lines (Grabbe 1999 21).
} 
gets what and who does not. With the publication, first, of the avis describing economic and political conditions in these states up until May 1997, and second, the Commission's regular reports on the status of each country's preparations, this reporting procedure not only further entrenched the hierarchy of West over East, but also influenced relations among the applicants. The pendulum swung from candidate countries sometimes uniting against EU criticism, and at other times dividing over the different degrees of reform deemed necessary in each state.

At the same time, and indeed through much of the 1990s, a debate ran among EU member states over the development of a two-tier EU with 'core' states pursuing the integration project further and 'periphery' states maintaining greater sovereignty. For CEE, the implications of this key debate for incoming states were interpreted as a coerced 'choice' between being first- and second-class European states -- as the EU-15 ruled out flexible options for the new CEE states, only further calling into question the validity of the EU's alleged anti-discrimination principles (Smith 108).

Despite the nature of the process, accession negotiations finally opened in 1998 between the EU and six states - Hungary, Slovenia, Cyprus, Poland, Estonia, and the Czech Republic. Six other applicants followed - Bulgaria, Romania, Latvia, Lithuania, Malta, and Slovakia - when negotiations opened with this second group in 2000. They were completed in December 2002 - with the exception of Bulgaria and Romania which eventually joined in 2007. For the most part, CEE candidates were expected to adopt the EU's acquis wholesale, leaving many CEE states to set up offices charged with the task of approving and implementing EU law without having to endure lengthy parliamentary debate. The speeding up of the process of harmonizing with EU law has been particularly important in spurring concern that the EU is exporting its democratic deficit to CEE.

The bigger worry lies in the illiberal export of EU liberalism, particularly through extending Europe's minority rights regime only to CEE countries, the 
haphazard application of anti-discrimination policy of the Single Market (mostly in cases not harmful to 'older' member states' sensitive sectors), and that the four Single Market freedoms that do not mix well with the after-effects of the drive to create ethnically pure nation-states. Bringing down borders for free movement, particularly concerning land purchases, can revitalize fears concerning sovereignty over formerly contested land areas that experienced population expulsions - a key part of the drive to create ethnically pure nation states.. In this way, the Single Market freedoms can lead to questions over who owns what and potentially also questions about sovereignty.

\section{Works Cited}

"Agenda 2000: Stengthening and Widening the European Union." Brussels: European Commission, 1997.

Bartoszewski, Władysław. Above Divisions: Selected Speeches and Interviews JulyDecember 2000. Warsaw: Ministry of Foreign Affairs, 2001.

Bruszt, Laszlo.. "Making Markets and Eastern Enlargement: Diverging Convergence," in The Enlarged European Union: Diversity and Adaptation, Ed. Peter Mair and Jan Zielonka. London: Frank Cass, 2002.

Bulletin of the European Communities, Vol. 26, No. 6, 1993.

Cernat, Lucian. "Can Regional Integration Arrangements Enforce Trade Disciplines?." Paper presented at the Young Scholars Conference on the Impact of Europeanization on Politics and Policy in Europe, University of Toronto, 2004.

de Weydenthal, Jan B. "Czechoslovakia, Hungary, and Poland Gain Associate Membership in the EC." RFE/RL Research Report, Vol. 1, No. 6, 1992. 1993.

"EC Keeps Central Europe at Arm's Length". RFE/RL Research Report Vol. 2, No. 5,

European Information Service. European Report External Relations No. 1578, April 12, 1990.

Frankel Paul, Ellen, Fred D. Miller, Jr., and Jeffrey Paul. Liberalism and the Economic Order. Cambridge: Cambridge University Press, 1993. 
Good, David F. Economic Transformation in East and Central Europe: Legacies From the Past and Policies for the Future. London: Routledge, 1994.

Grabbe, Heather. "A Partnership for Accession? The Implications of EU Conditionality for the Central and East European Applicants." European University Institute Working Paper No. 99/12. Florence: European University Institute, 1999.

. "The Sharp Edges of Europe: Extending Schengen Eastwards." International Affairs, Vol. 76, No. 3, 2000.

. "How does Europeanization affect CEE governance? Conditionality, diffusion and diversity." Journal of European Public Policy, Vol. 8, No. 6, 2001.

Grzymala-Busse, Anna and Abby Innes. "Great Expectations: The EU and Domestic Political Competition in East Central Europe." East European Politics and Societies, Vol. 17, No. 1, 2003.

Holmes, Stephen. “A European Doppelstaat?" East European Politics and Societies, Vol. 17, No. 1, 2003.

Jacoby, Wade. "Priest and Penitent: The European Union as a Force in the Domestic Politics of Eastern Europe." East European Constitutional Review, Vol. 8, No. 1-2, 1999.

Keat, Preston. "Penalizing the Reformers: Polish Steel and European Integration." Communist and Post-Communist Studies 33, 2000.

Kelley, Judith. "Membership, Management, and Enforcement: European Institutions and Eastern Europe's Ethnic Politics." Paper presented at the Annual Meeting of the American Political Science Association, 29 August-1September, Boston, MA, 2002. . Ethnic Politics in Europe: The Power of Norms and Incentives. Princeton: Princeton University Press, 2004.

Laffan, Brigid. "Democracy and the European Union." In Developments in the European Union, Ed. Laura Cram, Desmond Dinaan, and Neill Nugent. London: Macmillan Press Ltd., 1999.

Lilla, Mark. The Other Velvet Revolution: Continental Liberalism and Its Discontents. Dædalus, Vol. 123, No. 2, 1994.

Maresceau, Marc. "Pre-accession.” In The Enlargement of the European Union, Ed. Marise Cremona. Oxford: Oxford University Press, 2003 
Moravscik, Andrew. "Preferences and Power in the European Community: A Liberal Intergovernmentalist Approach." Journal of Common Market Studies, Vol. 31, No. 4, 1993.

Pollack, Mark A. “A Blairite Treaty? Neoliberalism and Regulated Capitalism in the Treaty of Amsterdam." In European Integration After Amsterdam: Institutional Dynamics and Prospects for Democracy. Ed. Karlheinz Neunreither and Antje Wiener. New York: Oxford University Press, 2000.

Senior Nello, Susan. "The Impact of External Economic Factors: The Role of the IMF." In Democratic Consolidation in Eastern Europe: International and Transnational Factors (Vol. 2). Ed Jan Zielonka and Alex Pravda. Oxford: Oxford University Press, 2001.

Smith, Karen E. "The Evolution and Application of EU Membership Conditionality." Iin The Enlargement of the European Union. Ed Marise Cremona. Oxford: Oxford University Press, 2003.

Smolar, Aleksander and Magdalena Potocka. "History and Memory: The Revolutions of 1989-91.” Journal of Democracy, Vol. 12, No. 3, 2001.

Suda, Zdenek and Jiri Musil, eds. The Meaning of Liberalism: East and West. Budapest: Central European University Press, 2000.

Switalski, Piotr. “An Ally for the Central and Eastern European States.” Transition Vol. 1, No. 11, 1995.

Szacki, Jerzy. Liberalism After Communism. Budapest: Central European University Press, 1996.

Tesser, Lynn. "The Geopolitics of Tolerance: Minority Rights Under EU Expansion in East-Central Europe." East European Politics and Societies, Vol. 17, No. 3, 2003.

Weitz, Richard. "The Expanding Role of the Council of Europe." Report on Eastern Europe Vol. 1, No. 34, 1990.

“The CSCE's New Look.” RFE/RL Research Report Vol. 1, No. 6, 1992.

"White Paper 1995: Preparation of the Associated Countries of Central and Eastern Europe for Integration into the Internal Market of the Union.” European Commission, May 1995. 